\section{E-LOGOS}

ELECTRONIC JOURNAL FOR PHILOSOPHY ISSN 1211-0442

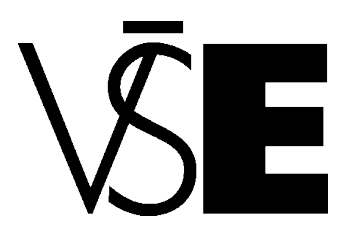

University of Economics

Prague

\title{
Hayekova kritická reflexe hranic rozumu
}

\author{
Václav Řezníček
}

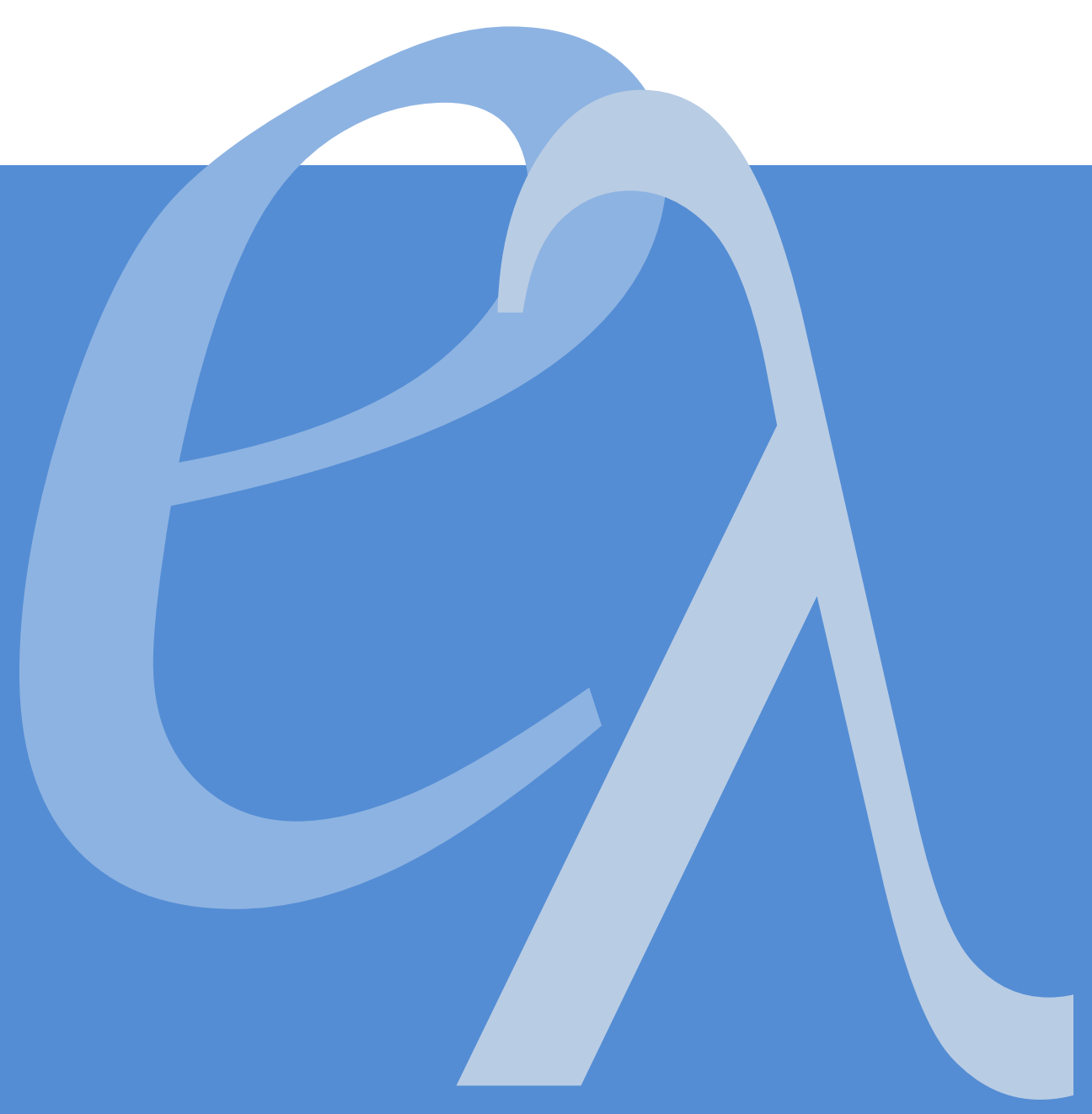




\section{Abstract}

This document was created after several years of studying the work of an important social-science thinker of the twentieth century Friedrich August von Hayek (is also based on reading some of Hayek's interpreters and "inspirators") and was written as the final work of a minor specialization "Philosophy" at the University of Economics, Prague. The author has researched the topics in several previous works. Devoted to this time he presents a more comprehensive picture that deals with explanation of issues with emphasis on the interrelationship between ideas and phenomena. For clarity, the text is structured into chapters. After a short introduction the author deals with definition of the fundamental (according to Hayek strictly distinguished from each other) concepts, which are spontaneous order and organization. Following chapter notes the origins of constructivist rationalism, more precisely, thinking of René Descartes, the philosopher whom Hayek called "standing at the birth of an unlimited belief in reason." Another chapter is devoted to David Hume, whose argument Hayek often "enthusiastically quotes" and provides "support" for his antirationalist approach. Then, the text focuses on the spontaneous order of society (more accurately, market, especially on the question of justice and liberty) and presents an important Hayek's concept - dispersed knowledge in society. Finally, the author briefly discusses current use of Hayek's extensive legacy. This paper is primarily focused on the idea that clearly permeates Hayek's work and provides him with a crucial argument for explanation of the phenomena in society, namely the idea of our knowledge limitations. This paper aims on drawing attention to Hayek's thinking through selected topics, which focus on critical reflection boundaries of reason with reference to its significance and implications.

\section{Abstrakt}

Tento dokument vznikl po několikaletém studiu díla významného společenskovědního myslitele dvacátého století Friedricha Augusta von Hayeka (vychází též z četby jeho interpretů a některých „inspirátorů“) a byl sepsán pro účely závěrečné práce ve vedlejší specializaci Filosofie na Vysoké škole ekonomické v Praze. Autor se rozebíraným tématům již v několika svých dřívějších statích věnoval. Tentokrát však presentuje ucelenější pohled, jehož cílem je vyložit problematiku s akcentem na vzájemné souvislosti jevů a myšlenek. Pro přehlednost je text strukturován do kapitol. Po krátkém úvodu se věnuje vymezení fundamentálních (Hayekem resolutně od sebe odlišovaných) pojmů, kterými jsou spontánní řád a organizace. Navazuje kapitola upozorňující na počátky konstruktivistického racionalismu, resp. na myšlení René Descarta, Hayekem označovaného za filosofa stojíćího u zrodu neomezené víry $\mathrm{v}$ rozum. Další kapitola je věnována Davidu Humovi, jehož teze Hayek častokrát "nadšeně cituje“ a který poskytuje "oporu“ jeho anti-racionalistickému př́stupu. Poté se text soustředí na spontánní řád trhu 
(zejména pak na otázku spravedlnosti a svobody) a presentuje Hayekův významný koncept ve společnosti rozptýlených znalostí. Nakonec autor krátce diskutuje dnešní uplatnění Hayekova rozsáhlého odkazu. Předkládaná práce se primárně zaměřuje na ideu, která jednoznačně prostupuje celým Hayekovým dílem a poskytuje mu zcela zásadní argument pro vysvětlování jevů ve společnosti, totiž na ideu omezenosti našeho poznání. Cílem př́spěvku je upozornit na Hayekovo myšlení prostřednictvím vybraných témat, přičemž se $\mathrm{v}$ případě těchto soustředit na kritickou reflexi hranic rozumu s poukazem na její význam a důsledky.

\section{Keywords}

Spontaneous order, organization, dispersed knowledge, constructivist rationalism, catallaxy, justice, liberalism, liberty.

\section{Klíčová slova}

Spontánní řád, organizace, rozptýlená znalost, konstruktivistický racionalismus, katallaxe, spravedlnost, liberalismus, svoboda. 
„Zdroje a potřeby existuji pro praktické účely pouze prostřednictvím té skutečnosti, že o nich někdo ví, a všichni lidé dohromady budou o nich vždy vědět nekonečně více, než kdy o nich může vědět ta nejkompetentnějši autorita. "

Z ideje hranic našeho poznání prostupující celým Hayekovým dílem vyvstává argument o nutně omezené (zlomkovité) znalosti faktů, který lze při vysvětlování jevů ve společnosti označit za jeho základní. ${ }^{2}$ Jelikož ambicí následujícího textu není a ani nemůže být výklad díla významného společenskovědního myslitele $\mathrm{v}$ jeho úplnosti, dotkneme se pouze vybraných témat, přičemž se v případě těchto zaměříme na Hayekovo rozpracování výše naznačené základní myšlenky s poukazem na její význam a důsledky.

Vídeňský rodák se zkoumání povahy lidského poznání rozsáhle věnoval. Dospěl k tvrzení, že individuum trpí "osudovým zakletím do parciality“, ${ }^{3}$ přičemž zároveň chce saturovat potřebu porozumět celku. Vzniká tak rozpor, který se mu daří překonávat namísto snahy o porozumění jednotlivostem (kterážto snaha je v případě komplexního celku marnou) především spolehnutím se na schopnost "abstrakce", 4 tedy na schopnost porozumět „obecným“ principům a pravidlům. „Lidské poznání se zdokonalovalo nikoli hlavně tím, že bylo s to pojmout stále větší množství faktů, nýbrž tím, že se spoléhalo na abstrakci jako na nepostradatelný prostředek mysli, jenž jí dává schopnost zacházet s realitou, kterou nemůže plně ovládnout. “5 Hayekovo tázání se po způsobech poznávání je zřetelně „instrumentální povahy“. Je totiž „přípravou na to, aby mohl naplnit svou hlavní celoživotní ambici... totiž

\footnotetext{
${ }^{1}$ Píše profesor Hayek, který upozorňuje, že „„v této souvislosti je důležité mít na paměti, že statistické celky, na něž, jak je častou domněnkou, by se mohla centrální autorita spoléhat ve svých rozhodnutích, se tvoři vědomým odhlédnutím od zvláštních podmínek místa a času." Dále dodává, že „Úspěšné řešení proto nelze zakládat na autoritě přímo se zabývající objektivními fakty, nýbrž musí být založeno na metodě, která využívá poznání, jež je rozptýlené mezi všemi členy společnosti, na poznání, o němž centrální autorita $\mathrm{v}$ jakémkoliv konkrétním př́ípadě neví ani to, kdo je vlastní nebo jestli vůbec existuje." HAYEK, F. A. Kontrarevoluce vědy; Studie o zneužívání rozumu. Praha: Liberální institut, 1995. překl: J. Pavlík, D. Slouková. ISBN 80-85787-87-3, str. 92 a 97.

${ }^{2}$ Za základní Hayekův argument jej označuje i Tomáš Ježek ve svém článku (př́spěvku) publikovaném v knize (Srov. SCHWARZ, Jiří. Za kolektiv autorů, HAYEK SEMPER VIVUS. Praha: Liberální institut, 2000. ISBN 80-86389-03-0, str. 127.), kde cituje z díla Právo, zákonodárství a svoboda: „Po čtenářovi této knihy musím chtít, aby měl po celou dobu na paměti fakt nezbytné a nenapravitelné neznalosti každého jedince týkající se většiny jednotlivých faktů, která jednání všech četných členů lidské společnosti determinují... z této nezbytné neznalosti většiny jednotlivostí, které vstupují do řádu velké společnosti, pramení ústřední problém společenského řádu..."

${ }^{3}$ Takového označení používá Tomáš Ježek ve svém článku publikovaném v knize (Srov. SCHWARZ, Jiř́i. Za kolektiv autorů, HAYEK SEMPER VIVUS. Praha: Liberální institut, 2000. ISBN 80-86389-03-0, str. 130.).

${ }^{4}$ HAYEK, F. A. Právo, zákonodárství a svoboda: nový výklad liberálních principů spravedlnosti a politické ekonomie / Friedrich August von Hayek, 2. vyd. - Praha: Academia, 1994, dotisk 1998. 415 s. Přeložil Tomáš Ježek. Orig.: Law, Legislation and Liberty, ISBN 80-200-0241-3, str. 34-35.

${ }^{5}$ Srov. Tomáš Ježek v (SCHWARZ, Jiř́i. Za kolektiv autorů, HAYEK SEMPER VIVUS. Praha: Liberální institut, 2000. ISBN 80-86389-03-0, str. 130.).
} 
podat důkaz, že socialismus (a snaha o vědecké celospolečenské centrální řízení vůbec) je omyl a scestí. ${ }^{\prime 6}$

\section{Spontánní řád trhu (společnosti) vs. organizace}

Vyjděme z "komplexního“ charakteru abstraktního (endogenního) tržního řádu ${ }^{7}$ (kosmos), který je u Hayeka v opozici proti (exogennímu) institucionálnímu ráau organizace (taxis). Na rozdíl od vědomě a záměrně (účelově) vytvořeného systému (majícího charakter produktu, resp. artefaktu), ${ }^{8}$ kterému jsme schopni jako jeho původci v detailech porozumět a lze ho "účinně“ řídit, je trh komplexním systémem, ${ }^{9}$ jenž má ex definitione v potenci nabýt jakéhokoli stupně složitosti (složenosti) $^{10}$ a který principiálně nelze $\mathrm{v}$ detailech vysvětlit. Jsme schopni porozumět pouze (obecným) principům fungování komplexních systémů, což má za následek problémy při pokusech jejich účelové konstrukce (a řízení). Spontánní řád trhu je, jak Hayek zdůrazňuje, nikým „záměrně nevytvořenou ${ }^{11}$ abstraktní strukturou založenou na abstraktních vztazích, která může přetrvávat kvantitativní (i

\footnotetext{
${ }^{6}$ Tamtéž, str. 130-131.
}

${ }^{7}$ Hayek vymezuje řád obecně jako „,takový stav věcí, v němž se velký počet prvků různých druhů má k sobě tak, že znalost nějaké časové nebo prostorové části celku nám dovoluje vytvářet správná očekávání týkající se zbytku, nebo alespoň očekávání, která mají dobrou pravděpodobnost, že se ukáží jako správná.“Definice zní v originále: „A state of affairs in which a multiplicity of elements of various kinds are so related to each other that we may learn from our acquaintance with some spatial or temporal part of the whole to form correct expectations concerning the rest, or at least expectations which have a good chance of proving correct." HAYEK, F. A. LAW, LEGISLATION AND LIBERTY: A new statement of the liberal principles of justice and political economy. Reprinted 1993, 1998 by Routledge 11 New Fetter Lane, London. Volume 1 RULES AND ORDER, Zdroj dostupný v PDF. ISBN 0-415-09868-8, str. 36.

${ }^{8}$ Tedy účelovou činností tvưrce vytvořené organizace vzniklé zvnějšku v procesu „organizování".

9 „Hayek uvádí, že spontánní řády nemusejí být nutně složité, ale mohou dosáhnout jakéhokoliv stupně složitosti, nebot' stupeň složitosti spontánního řádu jakožto nezáměrného produktu lidské činnosti není omezen tím, co může lidská mysl zvládnout." PAVLÍK, Ján. F. A. Hayek a teorie spontánního řádu. 1. Praha: Professional Publishing, 2004. 805 s. ISBN 80-86419-57-6. K dispozici v elektronické formě v síti VŠE, str. 19.

10 Výraz "složitost" navozuje myšlenku o „obtížnosti“ závisející na (kognitivních) schopnostech pozorovatele (resp. hodnotitele), proto lze přesněji použít termínu "složenost", který klade důraz na skutečnost, že se jedná o vlastnost systému per se (systému jako takového, systému samého).

${ }^{11}$ Hayek cituje A. Fergusona: „The result of human action but not of human design.“ Jako o výsledcích lidského jednání, nikoliv však záměru, hovoří o jevech (kategorii jevů), které se staly předmětem zkoumání společenských věd. Uvedeno v (HAYEK, F. A. LAW, LEGISLATION AND LIBERTY: A new statement of the liberal principles of justice and political economy. Reprinted 1993, 1998 by Routledge 11 New Fetter Lane, London. Volume 1 RULES AND ORDER, Zdroj dostupný v PDF. ISBN 0-415-09868-8, str. 20.), v českém překladu na straně 28 (HAYEK, F. A. Právo, zákonodárství a svoboda: nový výklad liberálních principů spravedlnosti a politické ekonomie / Friedrich August von Hayek, 2. vyd. - Praha: Academia, 1994, dotisk 1998. 415 s. Přeložil Tomáš Ježek. Orig.: Law, Legislation and Liberty, ISBN 80-200-0241-3, str. 28). Hayek se odkazuje na práci Adama Fergusona (An Essay on the History of Civil Society, London, 1767, str. 187: „Národy náhodně narážejí na instituce, které jsou vskutku výsledkem lidského jednání, nikoli však provedením vědomého lidského záměru.“). Dále nutno poznamenat, že Hayek „bojoval“ proti „dělbě práce“ ve společenských vědách. Za neštěstí považuje „rozvod“ práva a ekonomie. 
kvalitativní) změnu jejích prvků a která vzniká a funguje díky respektování a podřizování se těchto prvků, (jednotlivců a organizací), ${ }^{12}$ jistým pravidlům (chování), “13 aniž by přitom znaly konkrétní účelnost dodržování pravidel pro fungování tržního řádu jako celku. „Miliony jednotlivců tak vytvářejí spontánní řád nevědomou14 interakcí a kombinací nezáměrných důsledků ekonomických činností účelově vedených pouze za snahou maximalizace užitku pro sebe sama.. ${ }^{15}$ Pokud egoisticky jednající „individuum ve své činnosti jedná v souladu s danými abstraktně-formálními pravidly, získává jeho jednání eticko-právní legitimitu, takže se nemusí starat o ty důsledky svých činů, které přesahují jeho individuální užitek."16 Dá se v souladu s Hayekem také říci, že "spolehnutí se na spontánní řády v jistém smyslu omezuje a v jistém smyslu rozšiřuje naši schopnost řídit. “17 Nerespektování jejich povahy má však neblahé důsledky, jichž je historický (společenskopolitický) vývoj dokladem.

12 Organizace jako uměle vytvořené řády jsou samy prvkem spontánního řádu, jak píše Hayek: „Rodina, farma, továrna, firma, korporace a různé asociace a veškeré veřejné instituce včetně vlády (která zaujímá velmi zvláštní postavení) jsou organizace, které všechny jsou integrovány do obsažnějšího spontánního rrádu..." Srov. HAYEK, F. A. Právo, zákonodárství a svoboda: nový výklad liberálních principů spravedlnosti a politické ekonomie / Friedrich August von Hayek, 2. vyd. Praha: Academia, 1994, dotisk 1998. 415 s. Přeložil Tomáš Ježek. Orig.: Law, Legislation and Liberty, ISBN 80-200-0241-3, 51-52.

13 Srov. ŘEZNíČEK, Václav. Spontánní řád trhu a Hayekův koncept rozptýlených znalostí [elektronický zdroj], květen 2010, 9 s. Seminární práce (pro předmět Teorie spontánního řádu a samoorganizace). VŠE v Praze, str. 4.

14 Ján Pavlík k tomu uvádí: „Spontánní řád trhu, který lze označit za systém nevědomého a nezáměrného vzájemného donucování všech všemi k maximalizaci úsilí o efektivní uspokojování potřeb, se projevuje jako předurčená harmonie, tj. v podobě nikým neplánované synchronické a diachronické koordinace nesčíslného množství svobodných lidských aktivit (záměrných pouze k maximalizaci vlastního prospěchu). " O nedorozuměních kolem Hayekovy teorie spontánního řádu, Ján Pavlík v publikaci (SCHWARZ, Jiří. Za kolektiv autorů, HAYEK SEMPER VIVUS. Praha: Liberální institut, 2000. ISBN 80-86389-03-0. str. 60-61).

15 Srov. ŘEZNíČEK, Václav. Spontánní řád trhu a Hayekův koncept rozptýlených znalostí [elektronický zdroj], květen 2010, 9 s. Seminární práce (pro předmět Teorie spontánního řádu a samoorganizace). VŠ́E v Praze, str. 4.

${ }^{16}$ O nedorozuměních kolem Hayekovy teorie spontánního řádu; Ján Pavlík v publikaci (Srov. SCHWARZ, Jiří. Za kolektiv autorů, HAYEK SEMPER VIVUS. Praha: Liberální institut, 2000. ISBN 8086389-03-0. str. 60).

17 „V případě spontánních řádů můžeme určovat jejich abstraktní rysy tím, že budeme určovat některé z faktorů, jež je utvářejí, avšak jednotlivosti budeme muset přenechat okolnostem, které neznáme. A tak tím, že se spolehneme na spontánní uspořádávací síly, můžeme rozšírít rozsah nebo prostor řádu, jehož utváření můžeme vyvolat právě proto, že jeho jednotlivý projev bude záviset na mnohem větším počtu okolností, než je nám známo - a v prrípadě společenského řádu proto, že takovýto řád bude používat oddělených znalostí všech jeho různých členů, aniž by byly tyto znalosti kdy soustředěny $\mathrm{v}$ jedné mysli nebo byly předmětem těch procesů uvědomělé koordinace a adaptace, které mysl vykonává." HAYEK, F. A. Právo, zákonodárství a svoboda: nový výklad liberálních principů spravedlnosti a politické ekonomie / Friedrich August von Hayek, 2. vyd. - Praha: Academia, 1994, dotisk 1998. 415 s. Přeložil Tomáš Ježek. Orig.: Law, Legislation and Liberty, ISBN 80200-0241-3, str. 47-48. 


\section{Počátek neomezené víry v rozum}

Než budeme pokračovat $\mathrm{v}$ započatém tématu spontánního tržního řádu, věnujme se krátce prapočátkům problému (racionální konstrukce) v západoevropském myšlení. Pokusy o centrální celospolečenské řízení ve dvacátém století ztělesňovaly mylnou představu o „neomezené“ síle rozumu (tzv. „centrálního mozku“). Její původ sahá podle Hayeka až do novověku a za otce nebezpečné víry v racionální konstrukci označuje René Descarta, ${ }^{18}$ který stál na počátku způsobu myšlení vyznačujícího se odmítáním všeho, co nelze deduktivně odvodit z evidentních premis či axiomů. „Descartova (filosofická) cesta je cestou hledání nezpochybnitelných základů poznání. ${ }^{19}$ Smyslová zkušenost, ač netřeba ji úplně zavrhnout, nám jistě nedává jistotu sama o sobě... Tím pevným, nezpochybnitelným základem, se stane (samotná naše) pochybnost, resp. mimo jakoukoli pochybnost je to, co akty pochybování vykonává. Nelze zpochybnit naše pochybování, odtud Descartův známý výrok - Ego cogito ergo sum. ${ }^{20}$ To, co akty pochybování vykonává, je myšlení (duševní činnost), které se tak stává jediným pevným bodem. Abychom dospěli k poznatkům, které by před nás vystoupily jasně a zřetelně, musíme si tyto, získané ze smyslové zkušenosti, dokázat ve své mysli. Vzor jasnosti a zřetelnosti ${ }^{21}$

${ }^{18}$ V díle „Právo, zákonodárství a svoboda“ Hayek uvádí následující: „Tím velkým myslitelem, který nejúplněji vyjádřil základní ideje toho, co budeme nazývat konstruktivistickým racionalismem, byl René Descartes. Avšak zatímco on se zdržel toho, aby z nich odvozoval závěry pro společenské a morální argumenty, tyto argumenty byly vypracovány hlavně jeho o něco starším (avšak mnohem déle žijícím) současníkem Thomasem Hobbesem... O morálce, náboženství a právu, jazyku a písmu, penězích a trhu se přemýšlelo tak, jako by byly někým uvědoměle vytvořeny nebo alespoň jakoby za kterýkoli stupeň své dokonalosti vděčily takovému vědomému výtvoru. Toto intencionalistické nebo pragmatické vysvětlování lidské historie nalezlo svůj nejplnější výraz v pojetí vzniku společnosti společenskou smlouvou, nejprve $\mathrm{v}$ Hobbesovi a poté $\mathrm{v}$ Rousseauovi, který byl v mnoha ohledech přímým následovníkem Descartovým." HAYEK, F. A. Právo, zákonodárství a svoboda: nový výklad liberálních principů spravedlnosti a politické ekonomie / Friedrich August von Hayek, 2. vyd. Praha: Academia, 1994, dotisk 1998. 415 s. Přeložil Tomáš Ježek. Orig.: Law, Legislation and Liberty, ISBN 80-200-0241-3, str. 20-21.

19 „Pro toto hledání nezpochybnitelného a pevného si filosof prvé poloviny sedmnáctého století zvolí koncept pochybování, metodu skepse. Říká, že vše je hodno pochybnosti, o všem je možné pochybovat, ba dokonce je to snad nutné. Abychom se totiž dobrali pevných základů, abychom se dobrali jistoty, je třeba nejprve vše zbavit hávu samozřejmé platnosti. To je ovšem úkol vpravdě nadlidský, proto Descartes nahradí požadavek na znegování a prozkoumání všech poznatků prozkoumáním způsobů, jak tyto poznatky získáváme. Pokud obstojí způsob našeho poznávání vůči vznesenému požadavku jasnosti a zřetelnosti, pak obstojí i jeho výsledek." Srov. ŘEZNíČEK, Václav. René Descartes a konstruktivistický racionalismus [elektronický zdroj], květen 2010, 11 s. Seminární práce (pro předmět Filosofie II). VŠE v Praze, str. 3.

20 „I když jsem chtěl myslit, že vše je klamné, je nezbytně nutno, abych já, který tak myslím, existoval; a pozoruje, že tato pravda: myslím, tedy jsem, je tak pevná a jistá, že ani nejvýstřednější předpoklady skeptiků nejsou schopny jí otřást, soudil jsem, že ji mohu přijmout bez obavy za první zásadu filozofie, již jsem hledal.“ DESCARTES, René. Rozprava o metodě. Nakl. Svoboda, 1992. 67 s. ISBN 80205-0216-5, Z francouzského originálu přeložila Věra Szathmáryová-Vlčková; doslov a poznámky Jan Patočka. K dispozici v elektronické formě v síti VŠE, str. 26.

${ }^{21}$ Clare et distincte; V Rozpravě o metodě autor uvádí základní pravidla metody, prvním z nich je požadavek jasnosti a zřetelnosti. První pravidlo zní „nepřijímat nikdy žádnou věc za pravdivou, již bych sevidencí jako pravdivou nebyl poznal: tj. vyhnout se pečlivě ukvapenosti a zaujatosti; a 
vidí Descartes v racionální evidenci (ve smyslu matematiky). Zde lze spatřit ontologicky významný počin, subjekt se stává nositelem aktivity, subjekt je výsledkem a zároveň nositelem akce. Já myslím myšlené. ${ }^{22}$ Mám v mysli nějaký obsah (to je jsoucí v mém vědomí). Nemohu říci, že nějaký stůl je, ale že v mé mysli se nachází obsah, kterému říkám stůl. Základní filosofický výdobytek Descartův tkví ve zjištění, že nevnímáme jsoucna jako taková, ta nám nejsou přístupná, nevnímáme věci jako takové, nýbrž vnímáme vnímaná jsoucna a vnímané věci. První filosofie se už nebude zabývat jsoucnem jakožto jsoucím, ale obsahem naší mysli.“ ${ }^{23}$ „Bylo by chybné označit Descarta za hlavního představitele konstruktivistického racionalismu a tím jej (v podstatě) nenazývá ani Hayek. ${ }^{24}$ Uvádí však, že Descartem stanovená kriteria (požadavky na jasnost a zřetelnost) se stala tím, co dominovalo v následujícím ${ }^{25}$ pohybu filosofického myšlení. ${ }^{26}$ Za zrádnou Hayek označuje domněnku racionalistů, že za své úspěchy vděčí člověk pouze a jen rozumové úvaze, která mu jako jediná umožňuje dospět k prokazatelné pravdě. “27 Myšlenkově navazující „konstruktivistický racionalismus považuje veškeré lidské jednání, které není determinováno takto prokázanými pravdami, za iracionální, což se projevuje pohrdavým vztahem kartezianismu a osvícenství k tradicím, zvykům a dějinám vůbec. “28 Ač Descartes (který za garanta pravdivého poznání označil vrozenou ideu Boha) nebyl schopen udržet pozici, jíž dosáhl, „obratem k subjektu, který je schopen

nezahrnovat nic víc do svých soudů než to, co by se objevilo tak jasně a zřetelně mému duchu, abych neměl žádnou možnost pochybovat o tom." DESCARTES, René. Rozprava o metodě. Nakl. Svoboda, 1992. 67 s. ISBN 80-205-0216-5, Z francouzského originálu přeložila Věra Szathmáryová-Vlčková; doslov a poznámky Jan Patočka. K dispozici v elektronické formě v síti VŠE, str. 17.

22 "Nasazení filosofické pozice ve smyslu prioritního významu reflexe lidského já jakožto subjektu, ohniska myšlení a poznání - to je moment zásadní a rozhodující důležitosti, skrze který jsou určována východiska, metody, postupy, cíle i účel filosofování.“ HEMELÍK, Martin. Sešity k dějinám filosofie IV.: Přehled dějin novověké filosofie v XVII. století. 1. VŠE v Praze, 1997. 84 s. ISBN 80-7079-716-9. K dispozici v elektronické formě v síti VŠE.

${ }^{23}$ Srov. ŘEZNíČEK, Václav. René Descartes a konstruktivistický racionalismus [elektronický zdroj], květen 2010, 11 s. Seminární práce (pro předmět Filosofie II). VŠE v Praze, str. 4.

${ }^{24}$ Touto otázkou se ve své práci zabývá R. Tomečková (TOMEČKOVÁ, Radka. Dopouští se Descartes konstruktivistického omylu?: Kritika René Descartesa očima Fridricha A. von Hayeka, 2007. 64 s. Bakalářská práce. FHS UK.).

25 „Descartes v pojetí subjektivity pouze vykročil určitým směrem a teprve až překonání karteziánské metody umožňuje realizaci nových světů. Descartes byl přesvědčen o možnosti realizace panského postoje nad přírodou. Soudobé vědě však opanování prrírody nedostačuje, a tak vytváří umělé světy. Věda už jen nepoznává to, co je jaksi skryto za (ve) skutečností, ale tvoří nové skutečnosti, které $\mathrm{v}$ př́rodě nenalezneme." Srov. PSTRUŽINA, Karel. Konstruktivní typ racionality. Atlas filosofie vědy [online]. 1999-2002, [cit. 2010-05-05]. Dostupný z WWW: <http://nb.vse.cz/kfil/win/atlas1/konstruk.htm>.

${ }^{26} \mathrm{Viz}$ (HAYEK, F. A. LAW, LEGISLATION AND LIBERTY: A new statement of the liberal principles of justice and political economy. Reprinted 1993, 1998 by Routledge 11 New Fetter Lane, London. Volume 1 RULES AND ORDER. Zdroj dostupný v PDF. ISBN 0-415-09868-8, str. 10).

27 Srov. ŘEZNÍČEK, Václav. René Descartes a konstruktivistický racionalismus [elektronický zdroj], květen 2010, 11 s. Seminární práce (pro předmět Filosofie II). VŠE v Praze, str. 6.

${ }^{28}$ PAVLÍK, Ján. Hayek pro XXI. století. Liberální institut [online]. 2004, [cit. 2010-05-05]. Dostupný z WWW: <http://www.libinst.cz/stranka.php?id=38>. 
rozumově (jedině deduktivním způsobem) zakoušet okolní svět, poskytl základy myšlence Hayekem resolutně odmítané racionální organizace velké společnosti.“29

\section{David Hume: skepse k moci rozumu a „přirozené“ zákony}

Za filosofa, který na rozdíl od Descarta pochopil nutnost abstraktních zásad, označuje Hayek jiného novověkého filosofa, skotského skeptika Davida Huma, který tvoří společně s Angličanem Lockem a Irem Berkeleyem slavnou trojici britského empirismu. ${ }^{30}$ "Aby měla filosofie nárok nazývat se vědou, ${ }^{31}$ je podle Huma nezbytné zřetelně vymezit působiště lidského rozumu. Tím je tematicky vymezen projekt kritiky lidských poznávacích schopností. “32

${ }^{29}$ Srov. ŘEZNÍČEK, Václav. René Descartes a konstruktivistický racionalismus [elektronický zdroj], květen 2010, 11 s. Seminární práce (pro předmět Filosofie II). VŠE v Praze, str. 9. Ján Pavlík ve svém př́spěvku dále poukazuje, že „ve své kritice konstruktivistického racionalismu Hayek mírí implicite na tu skutečnost, že tato forma osudné domýšlivosti znemožňuje uchopit nahodilost jako takovou a také její roli v biologickém, kulturním a dějinném vývoji lidstva. Náhoda je totiž průsečíkem deterministických nutností probíhajících na různých úrovních reality, přičemž to, co se nutně odehrává v jedné úrovni, není logicky ex ante vydedukovatelné z nutného dění probíhajícího v druhé úrovni. Konstruktivistický racionalismus, který různé úrovně reálné i logické nutnosti nerozlišuje, a domnívá se, že nahodilost lze eliminovat jako takovou, tudíž nemůže v rámci své metodologie žádným způsobem uchopit... že v lidském (či polidšt'ujícím se) společenství mohou spontánně vyrůst normy a instituce, jež funkčně zajištúuí jeho prosperitu a rozvoj, aniž by se s předchozími vývojovými etapami spojovalo nutné pouto subjektivní či dokonce objektivní teleologické determinace..." Srov. Ján Pavlík v (SCHWARZ, Jiří. Za kolektiv autorů, HAYEK SEMPER VIVUS. Praha: Liberální institut, 2000. ISBN 80-86389-03-0, str. 29.).

${ }^{30}$ Hume ve své filosofii destruoval kategorie substance a kauzality a zároveň je označován za předchůdce a inspirátora evoluční teorie. J. Pavlík k tomu píše následující: „Hume je interpretoval jako nekorektní hypostazování prožitku mnohonásobného opakování prostorové koexistence počitků, resp. jejich časové sukcese (přičemž vysvětloval toto hypostazování jako důsledek empiricky zjistitelných regularit $\mathrm{v}$ psychických aktivitách člověka, tj. jako do určité míry nutný omyl); tento Humův počin znamenal zpochybnění newtonovské přírodovědy, jejíž pojetí prrírodních zákonů bylo ontologicky založeno právě ve zmíněných dvou kategoriích, a zároveň také zpochybnění bezpodmínečné platnosti mravního zákona (empirické poznání je s to zjistit jen to, co jest; vyvodit z toho, co jest, to, co má být, považuje Hume za nekorektní)... Humova destrukce kategorie substance kromě toho miřila proti aristotelskému konceptu mimočasových, boží myslí v identitě se sebou udržovaných druhových podstat (včetně tzv. lidské přirozenosti), která se v soudobé filosofii (a teologii) stále udržovala; Hume tak vytvořil podmínky pro nástup evoluční teorie vzniku a vývoje druhů." PAVLÍK, Ján. F. A. Hayek a teorie spontánního rádu. 1. Praha: Professional Publishing, 2004. 805 s. ISBN 80-86419-57-6. K dispozici v elektronické formě v síti VŠE, s. 241.

31 „Hume odlišuje metafysiku jako hluboké rozumování od filosofie pojednávající o svém předmětu způsobem lehkým a pochopitelným. Metafysika v podstatě není vědou, ale je bud' plodem ješitnosti usilující o proniknutí do věcí rozumu nepřístupných, anebo vzniká z úskoku obecných pověr, jež, nedovedouce hájiti se na půdě odkryté, hromadí toto zmotané trní, aby překryly a chránily své slabiny. Zahnáni byvše z odkrytého pole, utíkají lupiči ti do lesa a číhají tu, aby vpadli do ducha každým nestřeženým vstupem a udolali jej strachy a předsudky náboženskými." ŘEZNíČEK, Václav. David Hume a jeho Zkoumání o zásadách mravnosti [elektronický zdroj], leden 2011, 12 s. Seminární práce (pro předmět Filosofie III). VŠE v Praze, str. 4. a HUME, David. Zkoumání o zásadách mravnosti a Zkoumání o rozumu lidském. 368 s. Přeložil J. Škola. Vydal J. Laichter. Praha, 1899, Zkoumání o rozumu lidském, s. 173-174.

32Srov. ŘEZNíČEK, Václav. David Hume a jeho Zkoumání o zásadách mravnosti [elektronický zdroj], leden 2011, 12 s. Seminární práce (pro předmět Filosofie III). VŠE v Praze, str. 4. 
Úkol výzkumu přirozenosti lidského rozumu je „explicitním analytickým rozborem zkušenostních struktur. “33 Základ této analýzy spočívá v rozlišení obsahů mysli na původní imprese (dojmy) a ideje, které se dostavují bezprostředně: „Vztah obou typů mysli je představen jako nápodoba a základní diference je shledána v živosti a naléhavosti. Hume se domnívá, že toto rozlišení je platné ve všech aktivitách mysli a směrodatný způsob jeho fixace má podobu diference původní imprese (impressions) a myšlenky (thoughts) čili představy (ideas). "34 Podle Huma jsou všechny naše představy pouze kopiemi původních dojmů (impressions). Nic podle něj "nevíme substanciálně“, „neexistuje žádný substrát, který by udržoval počitky a přitom zůstával konstantní. Existuje pouze probíhání, tečení, a poznání je tak nutno odvodit z počitků (impresí), jelikož jinak bychom se pohybovali v oblasti fikce. Mezi jednotlivými počitky Hume také neshledává, kromě koexistence a sukcese, žádný vztah (působení). Ve snaze očistit naše poznání od představy kauzality ${ }^{35}$ se dostává k problematice pravděpodobnosti. “ ${ }^{36}$ "Vědomosti o vztahu příčiny a následku nikdy nedosahujeme rozumováním a priori, nýbrž vzniká zúplna ze zkušenosti... Nijaký předmět neobjevuje vlastnostmi jevícími se smyslům ani příčiny, které jej způsobily, ani účinky, jež z něho pojdou.“37 Podle Huma je tak pouze „pravděpodobné“, že po A nastane B, důležité však je, že to „neplatí nutně“. „Označení předchůdce evoluční teorie (kde právě náhoda hraje významnou roli) zajistily britskému mysliteli nepočetné výroky hovořící o původu pravidel nikoli v anticipaci jejich užitečnosti. “38 Skeptický postoj poukazující na omezenost lidského rozumu je pro Hayeka významným motivem filosofie Davida Huma, o kterého se tak "opírá“, a to i přes jeho (zejména v pozdějších fázích tvorby) ${ }^{39}$ prokazatelné směřování $\mathrm{k}$ utilitarismu pravidel. ${ }^{40}$

\footnotetext{
${ }^{33}$ Jak je uvedeno v publikaci (KUNCA, Tomáš; VACURA, Miroslav. Empirismus a analytická filosofie. 1. VŠE v Praze: Oeconomica, 2006. 120 s. ISBN 80-245-1023-5, s. 12.).

34 KUNCA, Tomáš; VACURA, Miroslav. Empirismus a analytická filosofie. 1. VŠE v Praze: Oeconomica, 2006. 120 s. ISBN 80-245-1023-5, s. 17.

35 Vnímání nám ukazuje následnost (post hoc), ne př́ičinnost (propter hoc).

${ }^{36}$ Srov. ŘEZNÍČEK, Václav. David Hume a jeho Zkoumání o zásadách mravnosti [elektronický zdroj], leden 2011, 12 s. Seminární práce (pro předmět Filosofie III). VŠE v Praze, str. 5-6.

${ }^{37}$ HUME, David. Zkoumání o zásadách mravnosti a Zkoumání o rozumu lidském. 368 s. Přeložil J. Škola. Vydal J. Laichter. Praha, 1899, Zkoumání o rozumu lidském, s. 190-191.

${ }^{38}$ Srov. ŘEZNÍČEK, Václav. David Hume a jeho Zkoumání o zásadách mravnosti [elektronický zdroj], leden 2011, 12 s. Seminární práce (pro předmět Filosofie III). VŠE v Praze, str. 5-6.

39 „Z některých Humových výroků je patrno, že se intuitivně dostal k teorii spontánní geneze pravidel, avšak zejména pak v díle Zkoumání o zásadách mravnosti dospěl do pozice utilitarismu pravidel ex ante (kam se některými výroky zařadil po bok Thomase Hobbese), kde zároveň naznačil spontánní (za absence rozumu) vznik pravidel distributivní spravedlnosti." ŘEZNíČEK, Václav. David Hume a jeho Zkoumání o zásadách mravnosti [elektronický zdroj], leden 2011, 12 s. Seminární práce (pro předmět Filosofie III). VŠE v Praze, str. 10.

40 Jak je pojednáno v práci (ŘEZNíČEK, Václav. David Hume a jeho Zkoumání o zásadách mravnosti [elektronický zdroj], leden 2011, 12 s. Seminární práce (pro předmět Filosofie III). VŠE v Praze, str. 11.).
} 
Ve Zkoumání o zásadách mravnosti ${ }^{41}$ je pro Huma „vpravdě ctnostným jednáním to, kdy chceme, aby nás ostatní chválili, přičemž zároveň chceme i takovými (jak nás vidí ti, co nás chválí) být ${ }^{42} \ldots$ Zdánlivě objektivně pravdivé celospolečensky konsensuální hodnocení garantované elementárním citem sympatie se však ukazuje být garantováno nedostatečně a Hume tak dochází k vědomí nutnosti stanovit nějaké všeobecně platné a neměnné měřítko. Ukazuje se jako nezbytné, aby se hodnocení realizovalo nejen na základě mravního citu (který nemusí být schopen postihnout důsledky určitého jednání), ale aby se při konstituci zmíněného měřítka hodnocení uplatnil instrumentální rozum. Ona všeobecná měřítka, která Hume nazývá pravidly spravedlnosti, jsou pravidly, která garantují stabilitu vlastnictví, jeho převod (přenos dohodou) a plnění slibů a smluv.“"33 Tyto "přirozené zákony Davida Huma“44

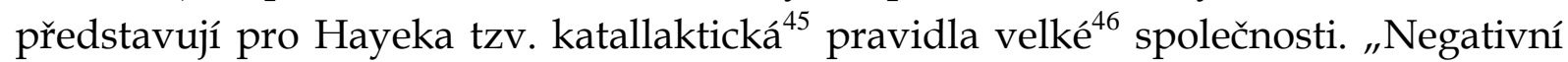
vlastností oněch abstraktně-formálních pravidel je podle Huma to, že ač jsou volena s cílem přispět obecnému prospěchu, je nemožné, aby byla ku prospěchu každému jednotlivému případu. Zde se opět dle Huma uplatňuje mravní cit, a to v našem (nezbytném) rozeznávání mezi nutností oddělenosti a stálosti majetku a pravidly přisuzujícími určitý majetek určitým osobám (která mohou záviset na veřejném prospěchu či soukromém citu). Mravní cit tak schvaluje rozdělování majetku v souladu slidskostí, neboli supluje zde princip distributivní spravedlnosti. ${ }^{47}$ Komutativní spravedlnost tedy u Huma nemůže být přirozeným produktem vývoje

${ }^{41}$ HUME, David. Zkoumání o zásadách mravnosti a Zkoumání o rozumu lidském. 368 s. Přeložil J. Škola. Vydal J. Laichter. Praha, 1899.

42 „Nesaturovaná touha být pochválen od druhých nás vede (v konečném důsledku) k jednání, kterým budeme obšt́astňovat blízké osoby nezávisle na našich egoistických zájmech. Takové jednání je pak okolím schvalováno $\mathrm{v}$ daleko větší miŕ̌e než obštastňování bližních za účelem získání budoucího prospěchu (tím, že nám budou zavázáni). Podle Huma toužíme po tom moci být hrdi sami na sebe, totiž býti si jisti, že nám opravdu náleží ctnost, za kterou jsme chválení - neboli toužíme po tom stát se (resp. býti) chvályhodnými.“ ŘEZNÍČEK, Václav. David Hume a jeho Zkoumání o zásadách mravnosti [elektronický zdroj], leden 2011, 12 s. Seminární práce (pro předmět Filosofie III). VŠE v Praze, str. 8.

${ }^{43}$ Srov. ǨEZNÍČEK, Václav. David Hume a jeho Zkoumání o zásadách mravnosti [elektronický zdroj], leden 2011, 12 s. Seminární práce (pro předmět Filosofie III). VŠE v Praze, str. 9.

44 Často citované, např. v př́ispěvcích Tomáše Ježka v (SCHWARZ, Jiř́i. Za kolektiv autorů, HAYEK SEMPER VIVUS. Praha: Liberální institut, 2000. ISBN 80-86389-03-0). „Podle Huma jsou však přirozené ve smyslu samozřejmosti, nikoliv přirozené z důvodu svého spontánního vzniku - naopak předpokládají rozum a úmysl." Jak je uvedeno v (ŘEZNíČEK, Václav. David Hume a jeho Zkoumání o zásadách mravnosti [elektronický zdroj], leden 2011, 12 s. Seminární práce (pro předmět Filosofie III). VŠE v Praze, str. 9.).

${ }^{45}$ Hayekovo označení pro tržní řád (katallaxe) je odvozeno z řeckého slova katallatein znamenajícím "směňovat".

${ }^{46}$ Hayek rozlišuje mezi „malou společností (tlupa nebo rodina - pokud na ni nahlížíme pouze v této rovině), kde každý jednotlivec může znát bezezbytku důsledky svého jednání a potřeby všech jejích členů a „velkou společnosti“" (případ trhu), kde velká většina důsledků a potřeb zůstává každému jednotlivci skryta. Ve velké společnosti je tudíž možná dohoda o (obecně akceptovatelných) prostředcích, ale není možná dohoda o konkrétních cílech. „Pojivem“ velké společnosti jsou tak ona pravidla.

${ }^{47}$ Poměr odměn dvou osob se má rovnat poměru jejich zásluh (o veřejné blaho). 
mravního citu, ale je ctností závisející na obecné užitečnosti (resp. užitku pro veřejné blaho plynoucím z dodržování pravidel). “48 Přes Humův utilitarismus pravidel (který lze interpretovat jako utilitarismus pravidel ex ante) ${ }^{49}$ Hayek upozorňuje na Humův výrok, že „pravidla mravnosti nejsou závěry našeho rozumu“ (the rules of morality are not conclusions of our reason), 50 který, pokud aplikujeme na ona "přirozená pravidla“ nutně „před svou formalizací působících v podobě mravních zákonů, hovoříme o spontánním rozvinutí citu nezávisle na rozumu a účelu. Jinými slovy zde Hume říká, že k poznání užitečnosti pravidel došlo až (dlouho) po jejich vzniku. Lze jej pak vykládat tím způsobem, jak to činil Hayek, tedy jako utilitaristu pravidel ex post. “51 Celkově vzato však nelze neregistrovat, že „Hayek Huma možná až př́liš jednostranně interpretuje ve prospěch své vlastní koncepce založené na spontánním řádu, nicméně ten se mu (tak) stává jednou z cenných opor v boji proti neomezené víře v rozum. “52

\section{Spontánní řád trhu: spravedlnost a svoboda}

Vrat'me se k problému tržního řádu. Pravidla, resp. jejich (ne)dodržování (jak již bylo naznačeno výše) je tím, s čím spontánní (tržní) řád padá a z čeho povstává. „Spontánní řády vyplývají z toho, že se jejich prvky podřizují jistým pravidlům chování, resp. jejich prvky sledují ve svých reakcích na své bezprostřední okolí jistá pravidla“53 $\mathrm{O}$ (liberálním) tržním řádu tak v žádném případě nelze hovořit jako o systému, který je „oproštěn od pravidel, jak by se snad na první pohled mohlo zdát a jak to někteří autoři, at' už propagátoři či kritici, proklamují, spojení - jistá pravidla však značí, že nemohou být jakákoli, ale musí mít určité vlastnosti. Těmi jsou negativita (musí se jednat o zákazy), obecná platnost (musí být aplikovatelná na neznámý počet budoucích případů), dále to musí být pravidla normativní (podmínkou je existence donucovací moci hledící na jejich dodržování) ${ }^{54}$ a nakonec

\footnotetext{
48 ŘEZNíČEK, Václav. David Hume a jeho Zkoumání o zásadách mravnosti [elektronický zdroj], leden 2011, 12 s. Seminární práce (pro předmět Filosofie III). VŠE v Praze, str. 9.

${ }^{49}$ Hume implicitně tvrdí, že člověk poznal užitečnost pravidel spravedlnosti před jejich zavedením.

${ }^{50}$ HUME, David. A treatise of human nature [online]. THE ONLINE LIBRARY OF LIBERTY: 1739, 2005 [cit. 2010-11-03]. Dostupné z <http://files.libertyfund.org/files/342/Hume_0213_EBk_v5.pdf>.

51 ŘEZNÍČEK, Václav. David Hume a jeho Zkoumání o zásadách mravnosti [elektronický zdroj], leden 2011, 12 s. Seminární práce (pro předmět Filosofie III). VŠE v Praze, str. 10.

52 Jak hovoř́ závěry práce (ŘEZNíČEK, Václav. David Hume a jeho Zkoumání o zásadách mravnosti [elektronický zdroj], leden 2011, 12 s. Seminární práce (pro předmět Filosofie III). VŠE v Praze, str. 11.).

53 Srov. HAYEK, F. A. Právo, zákonodárství a svoboda: nový výklad liberálních principů spravedlnosti a politické ekonomie / Friedrich August von Hayek, 2. vyd. - Praha: Academia, 1994, dotisk 1998. 415 s. Přeložil Tomáš Ježek. Orig.: Law, Legislation and Liberty, ISBN 80-200-0241-3, str. 48.

${ }^{54}$ Prosazování pravidel (uplatňování donucovací moci), je podle Hayeka hlavním úkolem vlády. Tím druhým, ale nepoměrně menším (vedlejším) je poskytování veřejných statků. $V$ plnění druhého úkolu může být vláda zastoupena, což je někdy ukazuje jako žádoucí.
} 
musí splňovat podmínku neúčelovosti. ${ }^{55}$ Existence pravidel a nutnost jejich dodržování pak odlišuje pravý liberalismus od toho, který Hayek označuje za falešný. “56 To je otázka, která souvisí s problematikou pojetí svobody (a odpovědnosti), o níž bude dále pojednáno.

Nevědomá $^{57}$ (neúčelová) koordinace má v př́ípadě spontánního tržního řádu za následek produkci nových předmětů spotřeby, které vznikly jako materializace ekonomických aktivit ${ }^{58}$ milionů jednotlivců, kteří nevědí nic o konkrétním spotřebiteli tyto předměty následně spotřebovávajícím. ${ }^{59}$ Nabízí se tak otázka, jakým zpơsobem se mají jednotlivé subjekty na trhu (úspěšně) orientovat. „Vyjděme z uvedeného tvrzení, že každé individuum jedná pouze v horizontu svých vlastních potřeb, totiž v zájmu maximalizace svého užitku. Pro takový účel poslouží systém cen. Ceny podle Hayeka informují prvky celého systému o tom, jak se mají zachovat, tedy co mají nakupovat, vyrábět atd. Nezávislý cenový systém je schopen koordinace účelové činnosti milionu jednotlivců a navíc žádný z účastníků nemusí mít o cenách všechny informace, ale stačí mu určité penzum o skutečnostech (cenách) týkajících se ho bezprostředně. Jelikož má trh charakter komplexního systému, jsme závislí na dělbě znalostí mezi jednotlivci.“60 "Cenový systém v konkurenčním prostředí umožňuje podnikatelům, aby sledováním relativně malého množství cen přizpůsobovali svou činnost aktivitám ostatních.“61 Pro „vyspělé“ civilizace je navíc,

\footnotetext{
55 To, že Hayek popsal pouze charakter pravidel (norem), ale již nehovoří o jejich obsahu, je mu vytýkáno některými kritiky. Takovým je např́klad Roman Joch v příspěvku nazvaném „Kritika konceptu donucení a odůvodnění svobody u F. A. Hayeka“ publikovaném v (SCHWARZ, Jiř́i. Za kolektiv autorů, HAYEK SEMPER VIVUS. Praha: Liberální institut, 2000. ISBN 80-86389-03-0, str. 96106).

56 Srov. ŘEZNíČEK, Václav. Spontánní rád trhu a Hayekův koncept rozptýlených znalostí [elektronický zdroj], květen 2010, 9 s. Seminární práce (pro předmět Teorie spontánního řádu a samoorganizace). VŠE v Praze, str. 4.

57 Ján Pavlík v této souvislosti uvádí Hayekem často citovaný Whiteheadův výrok, podle něhož se „civilizace rozvijí tím, že zvyšuje počet důležitých operací, které jsme schopni vykonat, aniž bychom na ně museli myslet". O nedorozuměních kolem Hayekovy teorie spontánního řádu; Ján Pavlík v publikaci (SCHWARZ, Jiří. Za kolektiv autorů, HAYEK SEMPER VIVUS. Praha: Liberální institut, 2000. ISBN 80-86389-03-0. str. 61). Zamyšlení-hodné jsou pak dopady (projevy) takového př́stupu (pokud je „obecně“ přiijímán).

58 Srov. SCHWARZ, Jiř́. Za kolektiv autorů, HAYEK SEMPER VIVUS. Praha: Liberální institut, 2000. ISBN 80-86389-03-0. str. 61.

${ }^{59}$ Z Hayekova důrazu na roli nevědomí čili spontaneity vyplývá, že tržní řád se nejefektivněji rozvijí, pokud jsou pravidla dodržována "v modu slepého a nezpochybnitelného respektu vůči tradici“. Srov. SCHWARZ, Jiří. Za kolektiv autorů, HAYEK SEMPER VIVUS. Praha: Liberální institut, 2000. ISBN 80-86389-03-0. str. 61.

60 „Čím je celek složitější, tím jsme závislejší na šîření informací mezi jednotlivci, jejichž samostatné činnosti jsou koordinovány neosobním mechanismem přenášení informací, kterému říkáme cenový systém." HAYEK, F. A. Cesta do otroctví (The Road to Serfdom). 2. vyd. Brno: Barrister \& Principal, 2008. 216 s. ISBN 978-80-87029-32-9, str. 57-58. a ŘEZNíČEK, Václav. Spontánní řád trhu a Hayekův koncept rozptýlených znalostí [elektronický zdroj], květen 2010, 9 s. Seminární práce (pro předmět Teorie spontánního řádu a samoorganizace). VŠE v Praze, str. 7.

${ }^{61}$ Srov. HAYEK, F. A. Cesta do otroctví (The Road to Serfdom). 2. vyd. Brno: Barrister \& Principal, 2008. 216 s. ISBN 978-80-87029-32-9, str. 57.
} 
jak píše Hayek, charakteristické, že lidé využívají mnohem většího množství znalostí, než sami mají, tedy profitují ze znalostí, které získali směnou (podle pravidel). Takové znalosti jsou neverbalizovatelné a úzce spjaté se svými nositeli. Není tak možné, aby existoval povolaný centrální plánovač, který by úspěšně realizoval celospolečenské řízení. “62

O otázce "spravedlnosti“ (i když je v „argumentaci“ často využívána) nemá podle Hayeka smysl v případě tržního řádu hovořit a to proto, že "spravedlnost je vlastností lidského chování." Za spravedlivý či nespravedlivý můžeme označit pouze stav, o kterém víme, kdo jej způsobil (resp. „pokud činíme někoho odpovědným za to, že jej přivodil nebo, že dovolil, aby nastal“ ${ }^{\prime 6}{ }^{63}$ "Aplikovat termín spravedlivý na jiné okolnosti, než jsou lidská jednání nebo pravidla, která je vedou, je kategorická chyba... I když nás náš nenapravitelný zvyk interpretovat fyzický svět animisticky nebo antropomorfně k takovémuto nadužití slov často vede a má nás k tomu, abychom hledali činitele odpovědného za všechno, co se nás týká, nemá smysl označovat stav skutečnosti za spravedlivý nebo nespravedlivý. " ${ }^{44}$ Nejlepším zpơsobem, jak porozumět tomu, jak fungování tržního systému vede nejen k utváření řádu, nýbrž také ke značnému zvýšení výnosů, které lidé mají ze svého úsilí, je podle Hayeka brát jej jakou hru (kterou nazývá hrou katallaxe). „Je to hra vytvářející bohatství (a ne to, co teorie her nazývá hrou s nulovým součtem), ${ }^{65}$ tj. hra, která vede ke zvětšení toků statků a vyhlídek všech účastníků na uspokojení jejich potřeb... O výsledku v této hře pak rozhoduje „nejvyšší dovednost, nadání a štěstí. “66 Je nutné zdơraznit, že se v tržním systému „hraje podle pravidel“, přičemž se tu uplatňují především pravidla komutativní (nikoli distributivní) spravedlnosti (viz katallaktická pravidla). ${ }^{67}$ Hayek tak připouští „riziko nezaslouženého pádu“ a upozorňuje, že „lidi je možné nechat jednat podle jejich vlastních znalostí a pro jejich vlastní účely jenom tehdy, jestliže odměna, které se jim dostává, závisí z části na okolnostech, které nemohou ani řídit ani předvídat. A mají-li se ponechat, aby byli ve

62 ŘEZNíČEK, Václav. Spontánní řád trhu a Hayekův koncept rozptýlených znalostí [elektronický zdroj], květen 2010, 9 s. Seminární práce (pro předmět Teorie spontánního řádu a samoorganizace). VŠE v Praze, str. 6-7.

63 Srov. HAYEK, F. A. Právo, zákonodárství a svoboda: nový výklad liberálních principů spravedlnosti a politické ekonomie / Friedrich August von Hayek, 2. vyd. - Praha: Academia, 1994, dotisk 1998. 415 s. Přeložil Tomáš Ježek. Orig.: Law, Legislation and Liberty, ISBN 80-200-0241-3, str. 163.

64 Srov. HAYEK, F. A. Právo, zákonodárství a svoboda: nový výklad liberálních principů spravedlnosti a politické ekonomie / Friedrich August von Hayek, 2. vyd. - Praha: Academia, 1994, dotisk 1998. 415 s. Přeložil Tomáš Ježek. Orig.: Law, Legislation and Liberty, ISBN 80-200-0241-3, str. 163.

${ }^{65}$ Což je důležité zdůraznit.

66 Srov. HAYEK, F. A. Právo, zákonodárství a svoboda: nový výklad liberálních principů spravedlnosti a politické ekonomie / Friedrich August von Hayek, 2. vyd. - Praha: Academia, 1994, dotisk 1998. 415 s. Přeložil Tomáš Ježek. Orig.: Law, Legislation and Liberty, ISBN 80-200-0241-3, str. 239.

${ }^{67}$ Viz „přirozené zákony“ Davida Huma. 
svém jednání vedeni svým vlastním morálním přesvědčením, nelze také morálně vyžadovat, aby souhrnné účinky jejich příslušných jednání na různé lidi odpovídaly nějakému ideálu distributivní spravedlnosti. V tomto smyslu je svoboda neoddělitelná od odměn, které často vůbec nesouvisejí se zásluhou a pocit'ují se tudíž jako nespravedlivé.“68 To v praxi vede (vedlo) k představě potřeby centrálně (nebo alespoň co nejvíc centralizovaně) řízeného systému, kde podmínka pozitivního rozvoje $\mathrm{v}$ důsledku svobodného využívání mezi jednotlivci rozptýlených znalostí není splněna, se všemi negativními důsledky. Dobrá společnost, jak píše Hayek, není (nebude) ta, kde panuje přrisně rovnostářský řád, ve smyslu, že se všichni budou mít stejně (podle zásluh) dobře, ale ta, „v níž je pravděpodobné, že šance kohokoli náhodně vybraného budou co možná největší. “ ${ }^{69}$

\section{Koncept rozptýlených znalostí}

„Pokud bychom měli veškeré relevantní informace a mohli bychom vyjít z dané soustavy preferencí a jestliže bychom měli $k$ dispozici všechny znalosti $o$ disponibilních zdrojích, pak bychom řešili čistě logický problém. Odpověd' na otázku, jak nejlépe použít disponibilní zdroje, by tedy byla obsažena již v našich předpokladech. Podmínky, které řešení tohoto optimalizačního problému musí splňovat, už byly vyčerpávajícím způsobem vypracovány a nejlépe je lze formulovat matematicky: řečeno nejstručněji, mezní míry substituce mezi dvěma statky nebo faktory musejí být stejné při všech jejich různých použitích. Ekonomicko-matematické metody, i když jsou důležitým krokem k řešení ekonomického problému společnosti, nám však zatím nedokázali poskytnout odpověd'. Překážkou zde je, že data, ze kterých ekonomicko-matematické metody vycházejí, nejsou nikdy za celou společnost dána $\mathrm{v}$ jediném mozku, který by z nich mohl odvodit důsledky, a nikdy být takto dána nemohou. ${ }^{70}$ Problém nemožnosti konstrukce racionálního ekonomického řádu je způsoben právě faktem, že znalost okolností, z níž musíme vycházet, nikdy neexistuje $\mathrm{v}$ koncentrované nebo integrované formě, avšak jen jako útržky neúplných a často rozporných informací, které jsou rozptýleny mezi všechny zúčastněné nezávislé jednotlivce. Ekonomický problém společnosti tak netkví pouze v otázce alokace disponibilních zdrojů ale také (zejména) v otázce,

${ }^{68}$ HAYEK, F. A. Právo, zákonodárství a svoboda: nový výklad liberálních principů spravedlnosti a politické ekonomie / Friedrich August von Hayek, 2. vyd. - Praha: Academia, 1994, dotisk 1998. 415 s. Přeložil Tomáš Ježek. Orig.: Law, Legislation and Liberty, ISBN 80-200-0241-3, str. 239.

${ }^{69}$ HAYEK, F. A. Právo, zákonodárství a svoboda: nový výklad liberálních principů spravedlnosti a politické ekonomie / Friedrich August von Hayek, 2. vyd. - Praha: Academia, 1994, dotisk 1998. 415 s. Přeložil Tomáš Ježek. Orig.: Law, Legislation and Liberty, ISBN 80-200-0241-3, str. 250.

${ }^{70}$ Hayek doslova píše: "The reason for this is that the "data" from which the economic calculus starts are never for the whole society "given" to a single mind which could work out the implications and can never be so given." HAYEK, F. A. The use of knowledge in society. American Economic Review. September [online]. 1945, vol.35, no. 4, s. 519-530. Dostupný z WWW: <http://www.econlib.org/library/Essays/hykKnw1.html>. 
jak zajistit nejlepší použití daných zdrojů známých jednotlivým členům společnosti pro účely, jejichž relativní význam znají opět pouze tito jednotlivci. Je to podle Hayeka problém využití znalostí, které nejsou nikomu dány ve své úplnosti. Jinými slovy tvrdí, že neexistuje žádný člověk, který by měl takové znalosti, aby byl schopen předpovídat jednání a potřeby všech lidí ve společnosti (což by zároveň znamenalo předvídat objevy, které ještě nebyly učiněny), ${ }^{71}$ a dodává, že mnohé ze současných sporů týkajících se ekonomické teorie i ekonomické politiky mají svůj společný původ v chybném pojetí povahy ekonomického problému společnosti. Toto chybné pojetí samo má pak (pra)počátek ve zcela mylném a neštastném přenášení myšlenkových návyků, které jsme si vytvořili při našem styku s přírodními jevy, na jevy společenské." 72

Ve svém psychologickém díle The Sensory Order (Řád smyslovosti) ${ }^{73}$ podává Hayek důkaz, že lidský mozek nedokáže $\mathrm{v}$ detailech vysvětlit své vlastní fungování. ${ }^{74}$ Právě proto, že mozek není s to poznat a předvídat své vlastní chování, není možné, aby jakýkoli plánovač znal do detailu jednání a činnosti všech milionů jednotlivců ve společnosti. Hayek sice připouští existenci stroje, který by svou informační kapacitou předčil lidský mozek, ale takový stroj by musel být napojen na mozky všech lidí, aby z nich (v reálném čase) čerpal informace. Tato skutečnost se zatím jeví co do možnosti realizace přinejmenším jako velmi nepravděpodobná. ${ }^{75}$

\section{Odkaz F. A. Hayeka (v) dnešní společnosti}

Praktickým důsledkem neznalosti všech relevantních faktů bylo, že znalosti, které lidé (rozptýlení jedinci) měli, zůstaly nevyužity. Centrálně řízená společnost pak upadala do nerozvinutosti a primitivismu. Nelze bagatelizovat vliv Hayekových textů (a rovněž textů dalších ekonomů rakouské školy) ${ }^{76}$ vemích bývalého východního bloku od osmdesátých let minulého století, které ukázaly, že socialismus

\footnotetext{
${ }^{71}$ Hayek upozorňuje, že konkurence je způsob objevování. Trh je tedy procesem objevování. HAYEK, F. A. Právo, zákonodárství a svoboda: nový výklad liberálních principů spravedlnosti a politické ekonomie / Friedrich August von Hayek, 2. vyd. - Praha: Academia, 1994, dotisk 1998. 415 s. Přeložil Tomáš Ježek. Orig.: Law, Legislation and Liberty, ISBN 80-200-0241-3, str. 325.

72 Podle (ǨEZNÍČEK, Václav. Data, informace, znalosti a jejich hodnota. VŠE v Praze, 2009. $71 \mathrm{~s}$. Bakalářská práce.) a (HAYEK, F. A. The use of knowledge in society. American Economic Review. September [online]. 1945, vol. 35, no. 4, s. 519-530), o problémech aplikace poznatků přírodních věd na společenské jevy (ve společenských vědách) více v Hayekově díle (HAYEK, F. A. Kontrarevoluce vědy; Studie o zneužívání rozumu. Praha: Liberální institut, 1995. překl: J. Pavlík, D. Slouková. ISBN 80-85787-87-3.).

${ }^{73}$ HAYEK, F. A. The Sensory Order; An Inquiry into the Foundations of Theoretical Psychology. The University of Chicago Press, 1952, 232 s. ISBN 0-226-32094-4.

${ }^{74}$ Jedná se o exaktní důkaz založený na kvantifikaci informace.

75 Srov. ŘEZNíČEK, Václav. Spontánní řád trhu a Hayekův koncept rozptýlených znalostí [elektronický zdroj], květen 2010, 9 s. Seminární práce (pro předmět Teorie spontánního řádu a samoorganizace). VŠE v Praze, str. 7.

${ }^{76}$ Dalším vlivným ekonomem byl Ludwig von Mises.
} 
je slepý a nikdy nemůže uspět. Jan Zahradil při př́ležitosti stého výročí Haykova narození poznamenal, že „v posttotalitních, postkomunistických společnostech na začátku 90. let se stal Hayek zcela po právu něčím jako prorokem. Jeho brilantní analýzy a jasná odmítnutí totalitních režimů nadchly všechny, kdo neměli možnost se $s$ jeho pracemi seznámit již dříve. Hledali u něj inspiraci především ti politici a ekonomové, kteří nechtěli mít nic společného se socialismem jakéhokoliv druhu a kteří se neštítili slova kapitalismus. ${ }^{\text {"77 }}$

Hayekova teorie však podléhá (a v minulosti podléhala) časté a viditelné dezinterpretaci. ${ }^{78}$ Jak píše Ján Pavlík: „Zvlášt' kormutlivou je okolnost, že dezinterpretované teorémy a chybné výklady liberalismu se přes mediální zprostředkování stačily zafixovat v povědomí laické, ale též odborné veřejnosti.“"79 Zejména je třeba upozornit na „falešné“ (ne)chápání liberalismu ${ }^{80}$ (na které upozorňoval sám Hayek) a s tím související vnímání a „prosazování

77 Jan Zahradil v publikaci (SCHWARZ, Jiři. Za kolektiv autorů, HAYEK SEMPER VIVUS. Praha: Liberální institut, 2000. ISBN 80-86389-03-0, str. 153.).

78 Ján Pavlík ve svém článku kritizuje „pseudohayekovský př́istup“ Václava Klause a jeho následovníků, který spočíval primárně v domněnce, že „V období transformačního procesu (a také obecně) probíhá vývoj ekonomiky v předstihu oproti utváření právních institucí, jejichž úkolem je poskytnout tomuto vývoji pevný právní rámec..." (SCHWARZ, Jiř́i. Za kolektiv autorů, HAYEK SEMPER VIVUS. Praha: Liberální institut, 2000. ISBN 80-86389-03-0, str. 73), Miroslav Ševčík k „deformaci Hayekova liberalismu“ uvádí, že „V rámci české ekonomické transformace došlo $\mathrm{k}$ aplikaci velmi okleštěné a deformované verze liberalismu, v níž se z myšlenkového dědictví klasického liberalismu uplatnilo jenom několik povrchně a nekoherentně pojatých floskulí a hesel, zatímco jeho podstatný obsah byl důsledně ignorován. To se projevilo zejména snahami neustále odkládat privatizaci bankovní sféry, které jsou v př́mém rozporu s teoretickými závěry rakouské školy, jež vidí v bankovnictví životní nerv ekonomického systému a jež zdůrazňuje, že státní zásahy do tohoto nervového centra mají zvlášt' pustošivé dopady na fungování tohoto systému jako celku. Ještě méně oprávněné je spojovat reálnou praxi české ekonomické reformy se jménem F. A. von Hayeka - přes neustálé omílání dezinterpretovaných frází o spontánním vznikání pravidel a práva u jejích vedoucích představitelů - nedošlo v jejím průběhu $\mathrm{k}$ aplikaci podstatné Hayekovy teze, podle níž svoboda a zákon jsou neoddělitelné.“ (Tamtéž str. 110.) Ján Pavlík uzavírá poznámkou, že „vzhledem k tomu, že to, co se uplatňovalo v rétorice i praxi české transformace, nebylo Hayekovo učení, nýbrž pokleslé hobbesovství, není noční můra právním nihilismem liberální vlády těžce postiženého českého kapitalismu $\mathrm{v}$ žádném případě praktickým důkazem neplatnosti Hayekovy teorie spontánního vzniku pravidel, nýbrž daleko spíše představuje důkaz neplatnosti jednostranného utilitarismu pravidel ex ante, popírajícího roli morálně-transcendentní fundace katallaktických pravidel, jak jej formulují Hobbes, Mises, Hoppe aj.“ Tamtéž, str. 90 (pozn. 53).

79 Srov. Ján Pavlík v (SCHWARZ, Jiří. Za kolektiv autorů, HAYEK SEMPER VIVUS. Praha: Liberální institut, 2000. ISBN 80-86389-03-0, str. 52.), který v závěru kapitoly o nedorozuměních kolem Hayekovy teorie píše: „Je zcela evidentní, že nesmyslná tvrzení o evoluci práva atp. nevznikla z žádné nezbytnosti teoreticky rozvíjet Hayekovo učení kvůli tomu, aby se dalo aplikovat na transformační proces. K tomu, aby se v Hayekově díle nalezl teoretický základ pro korektně vedenou transformaci, stačilo pouze číst je pozorně..." Ján Pavlík v publikaci (SCHWARZ, Jiřri. Za kolektiv autorů, HAYEK SEMPER VIVUS. Praha: Liberální institut, 2000. ISBN 80-86389-03-0, str. 90-91.)

${ }^{80}$ Ján Pavlík k tomu uvádí: „Když tedy schází moc a síla transcendentna a abstraktních ideologických principů, které donucovaly kdysi jedince $\mathrm{k}$ tomu, aby respektovali pravidla tržního řádu a utvářeli tak moderní civilizaci, zbývá již pouze jediné: sekulární moc důsledného a př́sného legálního sankcionování dodržování oněch pravidel. Jenže ona čistá vnějšková legalita je, jak víme, jen nutnou, nikoli však dostatečnou podmínkou efektivního uplatňování pravidel. Musí být k ní přidána moralita, a to nejlépe $\mathrm{v}$ podobě morální autority vedoucích politických osobností, které onen proces legálního sankcionování iniciují a řídí. Jenže moralita a její hlasatelé, morální proroci, se rodí, jak známo, 
svobody“ (jako volnosti bez ,pocitu“ odpovědnosti). ${ }^{81}$ Je nutné uvědomit si význam existence pravidel (správného chování) a zejména pak jejich dodržování. Ve spojení s reflexí naší omezené schopnosti rozumové konstrukce je toto oblast, na které by se mělo pracovat..

spontánně - a pokud tady nejsou, tak je nevytvoříme ani při největším úsilí. Nicméně přesto existuje jistý záblesk naděje: politik, který chce vstoupit do dějin a získat nehynoucí slávu tím, že napomůže ustavení fungujícího tržního řádu na bázi závazného a zvnitřnělého respektu lidí vůči pravidlům, jež tento řád zakládají, by si měl (utilitárně a macchiavellisticky) uvědomit, že svého cíle (slávy) mủže dosáhnout jen tehdy, když bude alespoň ve své rétorice úspěšně a hlavně důsledně předstírat, že je onou morální autoritou.“ PAVLÍK, Ján. Hayek pro XXI. století. Liberální institut [online]. 2004, [cit. 2010-05-12]. Dostupný z WWW: <http:// www.libinst.cz/stranka.php?id=38>.

${ }^{81}$ Nekompatibilita lidských plánů a nepřetržitý tok změn obhajují potřebu existence svobodného trhu, avšak svobodného v Hayekově pojetí svobody, které odpovědnost je nedílnou součástí, když píše následující řádky: „Svoboda neznamená pouze, že jednotlivec má jak př́iležitost volby, tak musí nést její břímě; znamená rovněž, že musí nést následky svého jednání a dostane se mu za ně ocenění či odsouzení. Svoboda a odpovědnost jsou neoddělitelné“. Hayeka ve své práci cituje Marek Št'astný v článku (ŠŤASTNÝ, Marek. Obhajoba svobody, demokracie, spravedlnosti a spontánního řádu v díle F. A. Hayeka. E-LOGOS: ELECTRONIC JOURNAL FOR PHILOSOPHY [online]. 1999 [cit. 2010-0106]. Dostupný z WWW: <http://nb.vse.cz/ kfil/elogos/ethics/Stastny1-99.htm>. ISSN 1211-0442.), na naznačené problémy je upozorněno v textu (ŘEZNíČEK, Václav. Spontánní řád trhu a Hayekưv koncept rozptýlených znalostí [elektronický zdroj], květen 2010, 9 s. Seminární práce (pro předmět Teorie spontánního řádu a samoorganizace). VŠE v Praze.). 


\section{Bibliografie}

DESCARTES, René. Rozprava o metodě. Nakl. Svoboda, 1992. 67 s. ISBN 80-2050216-5, Z francouzského originálu přeložila Věra Szathmáryová-Vlčková; doslov a poznámky Jan Patočka. K dispozici v elektronické formě v síti VŠE.

HAYEK, F. A. Cesta do otroctví (The Road to Serfdom). 2. vyd. Brno: Barrister \& Principal, 2008. 216 s. ISBN 978-80-87029-32-9.

HAYEK, F. A. LAW, LEGISLATION AND LIBERTY: A new statement of the liberal principles of justice and political economy. Reprinted 1993, 1998 by Routledge 11 New Fetter Lane, London. Volume 1 RULES AND ORDER, Volume 2 THE MIRAGE OF SOCIAL JUSTICE, Volume 3 THE POLITICAL ORDER OF A FREE PEOPLE. Zdroj dostupný v PDF. ISBN 0-415-09868-8.

HAYEK, F. A. Kontrarevoluce vědy; Studie o zneužívání rozumu. Praha: Liberální institut, 1995. překl: J. Pavlík, D. Slouková. ISBN 80-85787-87-3.

HAYEK, F. A. Právo, zákonodárství a svoboda: nový výklad liberálních principů spravedlnosti a politické ekonomie / Friedrich August von Hayek, 2. vyd. Praha: Academia, 1994, dotisk 1998. 415 s. Přeložil Tomáš Ježek. Orig.: Law, Legislation and Liberty, ISBN 80-200-0241-3.

HAYEK, F. A. The Sensory Order; An Inquiry into the Foundations of Theoretical Psychology. The University of Chicago Press, 1952, 232 s. ISBN 0-226-32094-4.

HAYEK, F. A. The use of knowledge in society. American Economic Review. September [online]. 1945, vol. 35, no. 4, s. 519-530, [cit. 2010-12-6]. Dostupný z WWW: <http://www. econlib.org/library/Essays/hykKnw1.html>.

HEMELÍK, Martin. Sešity k dějinám filosofie IV.: Přehled dějin novověké filosofie v XVII. století. 1. VŠE v Praze, 1997. 84 s. ISBN 80-7079-716-9. K dispozici $\mathrm{v}$ elektronické formě $\mathrm{v}$ síti VŠE.

HUME, David. A treatise of human nature [online]. THE ONLINE LIBRARY OF LIBERTY: 1739, 2005 [cit. 2010-11-03]. Dostupné v PDF z WWW: $<$ http://files.libertyfund.org/ files/342/Hume_0213_EBk_v5.pdf>.

HUME, David. Zkoumání o zásadách mravnosti a Zkoumání o rozumu lidském. 368 s. Přeložil J. Škola. Vydal J. Laichter. Praha, 1899.

KUNCA, Tomáš; VACURA, Miroslav. Empirismus a analytická filosofie. 1. VŠE v Praze: Oeconomica, 2006. 120 s. ISBN 80-245-1023-5. 
PAVLÍK, Ján. F. A. Hayek a teorie spontánního řádu. 1. Praha: Professional Publishing, 2004. 805 s. ISBN 80-86419-57-6. K dispozici v elektronické formě v síti VŠE.

PAVLÍK, Ján. Hayek pro XXI. století. Liberální institut [online]. 2004, [cit. 2010-0505]. Dostupný z WWW: <http:// www.libinst.cz/stranka.php?id=38>.

PSTRUŽINA, Karel. Konstruktivní typ racionality. Atlas filosofie vědy [online]. 1999-2002, [cit. 2010-10-10]. Dostupný z WWW: <http://nb.vse.cz/kfil/win/atlas1/konstruk.htm>.

ŘEZNÍČEK, Václav. Data, informace, znalosti a jejich hodnota. VŠE v Praze, 2009. 71 s. Bakalářská práce.

ŘEZNíČEK, Václav. David Hume a jeho Zkoumání o zásadách mravnosti [elektronický zdroj], leden 2011, 12 s. Seminární práce (pro předmět Filosofie III). VŠE v Praze.

ŘEZNíČEK, Václav. René Descartes a konstruktivistický racionalismus [elektronický zdroj], květen 2010, 11 s. Seminární práce (pro předmět Filosofie II). VŠE v Praze.

ŘEZNíČEK, Václav. Spontánní řád trhu a Hayekův koncept rozptýlených znalostí [elektronický zdroj], květen 2010, 9 s. Seminární práce (pro předmět Teorie spontánního řádu a samoorganizace). VŠE v Praze.

SCHWARZ, Jiří. Za kolektiv autorů, HAYEK SEMPER VIVUS. Praha: Liberální institut, 2000. ISBN 80-86389-03-0.

ŠŤASTNÝ, Marek. Obhajoba svobody, demokracie, spravedlnosti a spontánního řádu v díle F. A. Hayeka. E-LOGOS: ELECTRONIC JOURNAL FOR PHILOSOPHY [online]. 1999 [cit. 2010-01-06]. Dostupný z WWW: <http://nb.vse.cz/kfil/elogos/ethics/Stastny1-99.htm>. ISSN 1211-0442.

TOMEČKOVÁ, Radka. Dopouští se Descartes konstruktivistického omylu?: Kritika René Descartesa očima Fridricha A. von Hayeka, 2007. 64 s. Bakalářská práce. FHS UK. 


\section{E-LOGOS}

ELECTRONIC JOURNAL FOR PHILOSOPHY

Ročník/Year: 2011 (vychází průběžně/ published continuously)

Místo vydání/Place of edition: Praha

ISSN 1211-0442

Vydává/Publisher:

Vysoká škola ekonomická v Praze / University of Economics, Prague

nám. W. Churchilla 4

Czech Republic

13067 Praha 3

IČ: 61384399

Web: http://e-logos.vse.cz

Redakce a technické informace/Editorial staff and technical information:

Miroslav Vacura

vacuram@vse.cz

Redakční rada/Board of editors:

Ladislav Benyovszky (FHS UK Praha, Czech Republic)

Ivan Blecha (FF UP Olomouc, Czech Republic)

Martin Hemelík (VŠP Jihlava, Czech Republic)

Angelo Marocco (Pontifical Athenaeum Regina Apostolorum, Rome, Italy)

Jozef Kelemen (FPF SU Opava, Czech Republic)

Daniel Kroupa (ZU Plzeň, Czech Republic)

Vladimír Kvasnička (FITT STU Bratislava, Slovak Republic)

Jaroslav Novotný (FHS UK Praha, Czech Republic)

Jakub Novotný (VŠP Jihlava, Czech Republic)

Ján Pavlík (editor-in-chief) (VŠE Praha, Czech Republic)

Karel Pstružina (VŠE Praha, Czech Republic)

Miroslav Vacura (executive editor) (VŠE Praha, Czech Republic) 